Journal of Social and Development Sciences

Vol. 4, No. 6, pp. 268-277, June 2013 (ISSN 2221-1152)

\title{
Status of Knowledge Based Economy in the Kingdom of Saudi Arabia: An Analysis
}

\author{
${ }^{*}$ Omar Salem Bashehab ${ }^{1}$, Sanghamitra Buddhapriya ${ }^{2}$ \\ ${ }^{1}$ Hamdard University Ambience Island, Gurgaon, India \\ 2FORE School of Management New Delhi, India \\ *osob84@gmail.com
}

\begin{abstract}
This paper highlights on the emerging issues that compelled Saudi Arabia in transforming its economy to a knowledge-based one. It discusses the pillars of a knowledge-based economy i.e. the institutional model; education; research and development (R\&D); and information and communication technology (ICT) adopted by the World Bank Institute framework to analyze the status of a knowledge-based economy in Saudi Arabia. The primary objective of this article is to understand the status of the knowledgebased economy in the Kingdom of Saudi Arabia. Secondary data was collected for writing the paper. The nine developmental plans of Saudi Arabia (Ministry of Economy and Planning), Ministry of Education reports, Ministry of Communications and Information Technology reports, and Saudi Arabian Monetary Agency (SAMA) reports are some of the important sources of data. The government of Saudi Arabia has laid the foundation for transforming its economy to a knowledge-based one but more is required especially in the field of human resource development and innovation to expedite the easiness of the transforming process.
\end{abstract}

Keywords: Knowledge-Based Economy, Five Year Developmental Plans, Saudi Arabia, Education, Research and Development,

\section{Introduction}

The Kingdom of Saudi Arabia: Emerging Issues: The Kingdom of Saudi Arabia is the largest country in the Arabian Peninsula and the second largest in the Arab world. The Kingdom of Saudi Arabia is the biggest country of the six Gulf Cooperation Council (GCC) countries namely the United Arab Emirates, Kuwait, Bahrain, Qatar and Oman. Saudi Arabia is an Islamic monarchy, which was established by the late King Abdul'Aziz Al Saud on 23 September 1932. The establishment of the Kingdom, the discovery of oil in the Eastern province in the 1930s and the rebuilding of western countries after the World War Two, for which there was a great demand for oil were the three major factors that shaped the economy of modern Saudi Arabia. Saudi Arabia has an oil-based economy and possesses about one fifth of the worlds proven petroleum reserves. It is the largest exporter of oil and its revenue from oil was $90 \%$ out of its total budget revenue in 2010 (SAMA, 2011). The oil industry contributed 52.4\% to Saudi Arabia's GDP whilst private and government sectors contributed $29 \%$ and $18.6 \%$ respectively (SAMA, 2011). The total population of Saudi Arabia has increased from 7 million (11\% expatriates) in 1974 to 22.67 million (27\% expatriates) in 2004 (SAMOEP, 2010). In 2009, the total population reached 25.4 million (27\% expatriates) of which $43.4 \%$ are from the age group (15-39) (SAMA, 2011). Hence, the government is facing challenges in providing basic amenities like water, food, housing etc. One of the biggest challenges is providing jobs. In 2009, the Saudi unemployment rate was $10.5 \%$ of the total national labor force (SAMA, 2011).

Another factor for unemployment is the continuous increase of non-Saudi workers in the labor market over the past three decades. According to John Sfakianakis, the chief economist at Banque Saudi Fransi in Riyadh "The economy is capable of providing enough jobs but most of them will go to non-Saudis" (Mahdi, 2010). Being part of the World Trade Organization (WTO) from 2005, it has raised competition, which is being faced by national products in domestic and international markets. It has also increased the challenges faced by national workers where the labor market has become more selective of skills and the level of education pertaining to workers. In addressing these issues, the government of Saudi Arabia is striving to diversify its economy, enhancing its competitiveness and creating job opportunities for the Saudi population which is noticeable from its five year developmental plan, particularly its Eighth (2005-2009) and Ninth (2010-2014) Developmental Plans whereby the government has been focusing on transforming its economy into a 
knowledge-based economy. The primary objective of this article is to understand the status of the knowledgebased economy in the Kingdom of Saudi Arabia by studying the economic trend and the institutional model, education, investment in research, development, information, and communication technology.

An Assessment of the Knowledge Based Economy in the Kingdom of Saudi Arabia: The study "Knowledge economies in the Middle East and North Africa: Toward new development strategies" of Aubert and Reiffers (2003) refers to the conceptual framework and design which is systematically applied by the World Bank Institute to assess knowledge-based development strategies in different regions of the world. The framework indicates that developing a knowledge-based economy requires the following four pillars:

- "An economic and institutional model that provides incentives for the efficient creation, dissemination, and use of knowledge to promote growth and increase welfare;

- An educated and skilled population that can create and use knowledge;

- An innovative system composed of firms, research centers, universities, consultants, and other organizations that can tap into the growing stock of global knowledge, adapt it to local needs, and transform it into tangible products;

- A dynamic information infrastructure that can facilitate the effective communication, dissemination, and processing of information." (Aubert and Reiffers, 2003)

This paper adopts this framework and intends to elaborate on the status of the knowledge-based economy in KSA by assessing these four pillars. An attempt is made to analyze the economic and institutional model of Saudi Arabia, as well as the initiatives taken by the government for creating an educated and skilled population, innovative system focusing on research and development (R\&D) and information and communication technology (ICT).

The economic and institutional model of Saudi Arabia: Government's five-year developmental plan indicates the overall vision and the direction that the government is striving to achieve. Consequently, this paper discusses the Nine Developmental Plans (1970-2014) of Saudi Arabia to get an understanding of the government's initiatives towards developing a knowledge-based economy. The Eighth and Ninth Developmental Plans are discussed in detail during which the government's focus shifted towards the development of a knowledge-based economy. The Central Planning organization was established in 1965 and later became the Ministry of Planning in 1975. The first two developmental plans (1970-1980) focused on education, defense, transportation and infrastructure (SAMOEP, 1975). The Royal Commission of Jubail and Yanbu were established during that period to provide the needed infrastructure for hydrocarbon industries. As the first two developmental plans focused on high growth for all sectors with relatively the free importation of foreign workers, the Third Developmental Plan (1980-1985) aimed at achieving high growth more selectively and a better use of expatriate workers than expanding their numbers (SAMOEP, 1980). During that period, the spending on infrastructure declined and the focus shifted towards health, education and social services. The plan had focused on enhancing economic and management efficiency through improving administrative organization and government procedures. By the end of the third plan, most of the modern infrastructure was about to be completed. There were many tangible developments in the country for example, the overall capacity of the ports rose from 2 million tons in 1970 to around 50 million tons in 1985. Moreover, the student population rose from 597,000 to more than 2 million in the same period. However, to ensure more flexibility in government agencies, the planning methodology has been shifted in the Fourth Development Plan (1985-1990) from projects based towards program planning (SAMOEP, 1985). During the fourth plan period, the government focused on increasing the private sector investment and strengthening the economic cooperation with GCC countries.

The Fifth Developmental Plan (1990-1995) aimed at enhancing the infrastructure and the social services of the country through the expansion of the productive base of the economy by stimulating the private sector to invest in agriculture and manufacturing sectors and increasing Saudi employment in the private sector by reducing the number of foreign workers (SAMOEP, 1990). However, due to regional instability and the Gulf War in 1991, the plan was negatively affected as a result the government expenditure had focused more on consolidating the country's defenses. In the same context, the Sixth Developmental Plan (1995-2000) was prepared under extraordinary domestic and global conditions that prevailed in the aftermath of the Gulf War and the negative effect that hit the oil market (SAMOEP, 1995). Therefore, the plan had depended on three 
major themes. Developing and increasing the employment opportunities of Saudi labor, raising the level of economic efficiency in both government and private sectors and enhance the private sector role in the national economy. The long-term goals of the Seventh Development Plan (2000-2004) were to raise the efficiency of labor and increase employment (SAMOEP, 2000). The other goal was to improve services in different regions of the Kingdom. The plan had focused on creating a suitable environment to attract foreign direct investment (FDI). It had also aimed at building a national science and technology base to strengthen the development of technology. The Plan had emphasized on the development of knowledge and technical skills in order to enhance the ability of Saudi manpower to harness the benefits of rapid technological development The year 2000 witnessed the establishment of the Saudi Arabian General Investment Authority (SAGIA) as an initiative to encourage FDI in the country. That was after the announcement of Saudi Arabia to join the World Trade Organization (WTO). Saudi Arabia officially joined the WTO in December 2005.

The Eighth Developmental Plan (2005-2009): The Eighth Developmental Plan also stressed on the economic diversification, education and the activation of the role of women in society. The Plan focused on the development of science, technology and of information systems to support and promote scientific research and a knowledge-based economy (SAMOEP, 2005). Table (1) illustrates the attention given by the successive developmental plans to expenditures for development agencies. The table and the figures also show the changing priorities and areas of focus over the last eight developmental plans, (1970-2009).

Table 1: Actual Expenditures by Development Agencies, during the last Eight Development Plans (1970-2009), (\%)

\begin{tabular}{lllllllll} 
Development Sector & $\mathbf{1}^{\text {st }}$ & $\mathbf{2}^{\text {nd }}$ & $\mathbf{3}^{\text {rd }}$ & $\mathbf{4}^{\text {th }}$ & $\mathbf{5}^{\text {th }}$ & $\mathbf{6}^{\text {th }}$ & $\mathbf{7}^{\text {th }}$ & $\mathbf{8}^{\text {th }}$ \\
& $\mathbf{( 7 0 - 7 5 )}^{\mathbf{( 7 5 - 8 0}}$ & $\mathbf{( 8 0 - 8 5 )}$ & $\mathbf{( 8 5 - 9 0 )}$ & $\mathbf{( 9 0 - 9 5 )}$ & $\mathbf{( 9 5 - 0 0 )}$ & $\mathbf{( 0 0 - 0 4 )}$ & $\mathbf{( 0 5 - 0 9 )}$ \\
\hline Economic Resources & 27.7 & 28.0 & 30.7 & 20.4 & 10.0 & 11.5 & 11.2 & 12.2 \\
Human Resources & 20.6 & 14.7 & 18.4 & 33.0 & 48.0 & 51.5 & 57.1 & 55.6 \\
Social \& Health & 10.3 & 8.0 & 09.8 & 17.7 & 20.0 & 20.8 & 19.1 & 18.0 \\
Infrastructure & 41.4 & 49.3 & 41.1 & 28.9 & 22.0 & 16.2 & 12.6 & 14.2 \\
Total & 100 & 100 & 100 & 100 & 100 & 100 & 100 & 100 \\
\hline
\end{tabular}

Source: Ministry of Economy and Planning, KSA

It is noticed that the government's first priority during the first three developmental plans was on infrastructure development whereby the average expenditure reached 41.4, 49.3 and 41.1 percent respectively of the actual total expenditure of the development agencies, exceeding average expenditure on the development of economic, human, social and health resources. The reason behind that was its intention to establish an integrated base of infrastructures needed to accelerate socio-economic development. Since 1985, the government started paying more attention towards enhancing the capabilities of the Saudi labor force through increasing the absorptive capacity of universities, educational institutions, vocational training and technical colleges and improving standards of education. The government expenditure on human resource development increased from 18.4 percent in the third plan to 57.1 percent in the seventh plan. The number of graduates of secondary level had increased from 3,745 in 1969 to more than 321,042 in 2008. While the number of graduates of technical education and vocational training increased from 417 to 68,000 during the same period (SAMOEP, 2010). In the same context, the social and health services received a higher focus since the fourth plan whereby the government's expenditure almost doubled compared to the third plan reaching 17.7 percent. Then a steady increase continued through the fifth and sixth plan reaching 20.0 and 20.8 respectively.

The Ninth Developmental Plan (2010-2014): The main developmental sectors in the Ninth Development Plan are human resources development, social and health development, economic resources development, transport and communications, and municipal services and housing (SAMOEP, 2010). The government's planned expenditure on this plan is 67.2 percent more than the Eighth Developmental Plan. As shown in table 2 , the government is allocating around 51 percent of its expenditure budget towards human resources development which indicates the level of attention paid towards improving the output of education to match the expectation of the labor market, the social and health sector with around 19 percent followed by the economic resources, transport and communication and municipal and housing services with 15.76, 7.69 and 6.96 respectively. The Ninth Developmental Plan aims at eliminating poverty and increasing development in infrastructure, medical services, education, and housing. The government is aiming at decreasing the Saudi unemployment from 9.6 percent to 5.5 percent by investing substantially in human resource development. 
Table 2: Financial Allocations of Development Sectors Ninth Development Plan

\begin{tabular}{ll}
\hline Development Sector & During (2010-2014) \% \\
\hline Human Resources & 50.64 \\
Social \& Health & 18.96 \\
Economic Resources & 15.76 \\
Transport and Communication & 7.69 \\
Municipal and Housing Services & 6.96 \\
Total & 100 \\
\hline
\end{tabular}

Source: Ministry of Economy and Planning, KSA (2010)

As the economy transformed from agriculture to industry due to the industrial revolution, it is shifting again towards a knowledge-based economy due to the technological revolution. According to the Ninth Developmental Plan (2010-2014) report of Saudi Arabia, the knowledge-based economy is defined as "an economy that is capable of knowledge production, dissemination and use; where knowledge is a key factor in growth, wealth creation and employment, and where human capital is the driver of creativity, innovation and generation of new ideas, with reliance on information and communication technology (ICT) as an enabler" (SAMOEP, 2010). The Ninth Developmental Plan (2010-2014) is based on five major themes where the second theme is focusing on the "development of national manpower and increasing their employment". The Plan includes several programs and policies that aim to raise the capabilities of the national labor force. Moreover, the Plan addresses the issues of enhancing the "work culture", and instilling in the Saudi worker the values of diligence, creativity and innovation in order to become the "knowledge worker" required by the "knowledge economy" (SAMOEP, 2010).

The Ninth Developmental Plan (2010-2014) adopts a package of specific objectives and targets designed to guide the desired progress towards building a knowledge-based economy. To achieve these objectives, the plan adopts a set of policies, as well as programs for implementing each policy. The overall objectives are as follows:

- $\quad$ "Promoting human development, disseminating knowledge, and expanding the options available for acquiring knowledge, skills and experience.

- Reinforcing efforts to transfer and indigenize knowledge in all economic and social sectors.

- Upgrading the knowledge production capabilities of the Kingdom in economic and social fields.

- Raising the level and improving the content of knowledge in production and service activities of both public and private sectors.

- Providing the technical, administrative and organizational environment, as well as infrastructure, for information and communications technology.

- Reducing knowledge gaps among regions and increasing citizens' awareness of the importance of knowledge, as well as increasing the Arabic digital content" (SAMOEP, 2010).

- The Plan adopts the following policies to achieve the objectives of the drive towards a knowledgebased economy:

- "Adopting mechanisms for enhancing the dissemination of knowledge.

- Increasing the technology-transfer-and-indigenization capacities of the Kingdom.

- Continuing to increase public and private knowledge generation activities.

- Improving the knowledge content of goods and services produced in the Kingdom, in order to improve productivity and competitiveness.

- Sustaining the development of an appropriate knowledge management environment, in terms of technology, structure, legislation and funding.

- Raising the level of knowledge of members of the community." (SAMOEP, 2010)

The outcome of building a knowledge-based economy would contribute effectively to the achievement of balanced development, diversification of the economic base, and enhancement of the competitiveness of the national economy. 


\section{Initiatives taken by the government for creating educated and skilled population}

Education is the corner stone of economic and social development and a key factor for its sustainability. The ultimate objective of development is to achieve human welfare that is developed economically, socially and culturally which is depended upon having educated, skillful and productive citizens, who can uphold high moral and religious values and are proud of their civilization, while being open and tolerant to other civilizations and cultures. Interest in education is evident in the significant increase in the number of students, with Saudi students at all levels of general and higher education constituting $28 \%$ of total Saudi population in 2008. These achievements would not have been possible without full commitment in providing the necessary financial resources for expanding education at all levels. Financial allocations for human resources development (HRD) increased during 2005-2008 from approximately SR69.9 billion to about SR104.6 billion (SAMOEP, 2010), an annual average growth rate of $14.4 \%$, which confirms the commitment of the Kingdom to provide the required financial support for expanding educational opportunities. With the accomplishment of a major expansion of educational opportunities, qualitative development has become the top priority for building a knowledge society. In 2008, the number of government and private schools, apart from kindergartens, stood at 25.9 thousands covering all geographic regions and comprising 212,109 classrooms, with total enrollment crossing 4.7 million students (Table 3).

Table 3: Growth of Primary, Intermediate, Secondary Education From 1999 - 2008

\begin{tabular}{llll}
\hline & $\mathbf{1 9 9 9}$ & $\mathbf{2 0 0 8}$ & Growth \% \\
\hline Number of Schools & 21,252 & 25,902 & 18.0 \\
Number of Classrooms & 176,427 & 212,109 & 16.8 \\
Number of new Entrants: & & & \\
Primary & 379,083 & 420,008 & 9.7 \\
Intermediate & 343,353 & 385,519 & 10.9 \\
Secondary & 246,470 & 330,511 & 25.4 \\
All Level & 968,906 & $1,136,038$ & 14.7 \\
Number Enrolled: & & & \\
Primary & $2,259,849$ & $2,469,863$ & 8.5 \\
Intermediate & $1,035,363$ & $1,188,898$ & 12.9 \\
Secondary & 704,566 & $1,058,514$ & 33.4 \\
Total & $3,999,778$ & $4,717,275$ & 15.2 \\
Graduates of Secondary Schools & 164,629 & 321,042 & 48.7 \\
& & & \\
Number of Teachers & 329,256 & 436,526 & 24.6 \\
\% of Saudis & 88.0 & 94.3 & 6.7 \\
\hline
\end{tabular}

Source: Ministry of Education, KSA

The growth was accompanied by increased commitment of Saudi families in enrolling their children, boys and girls, in the educational system, with girls accounting for $47.5 \%$ of total Saudi students enrolled in general education in 2008. In the same year, schools for girls accounted for $49.7 \%$ of all schools and they had $51.6 \%$ of all teachers. The significant expansion of primary education is a major indicator of the success of the educational policies pertaining to providing educational opportunities to children. During the period from 1999 to 2008, the total number of students enrolled increased by $15.2 \%$, consisting of $8.5 \%$ growth at primary school, $12.9 \%$ growth at intermediate school and $33.4 \%$ growth at secondary school. During the same period, the number of secondary school graduates increased from 164.6 thousands to around 321 thousands with a growth of 48.7\%. Under the Eighth Developmental Plan, many universities were established across the Kingdom; where the total number of universities rose to 31 universities including 7 private universities. Moreover, the number of students registered in higher education reached 903.6 thousand in 2009. In the same context, the number of technical training centers increased from 4 with 417 graduates and 578 enrollments in 1970 to more than 62 with 8000 graduates and 17.6 thousand enrollments in 2009 (SAMA, 2011). As a result, the number of students enrolled in universities at bachelor's level, increased from 282,433 in 1999 to 759,914 in 2008 with an increase of $62.8 \%$ (Table 4). In addition, the total number of new entrants to universities reached 280,518 in 2008 compared to 83,486 in 1999, representing an increase of $70.2 \%$. Moreover, the number of graduates increased accordingly with the notable increase of entrants to 
higher education institutions. The total number of graduates at bachelor's level was almost 112,000 students in 2008 , compared with 38,000 in 1999 , representing a growth rate of about $66 \%$ (Table 4).

Table 4: Numbers of New entrants, Graduates and Enrolled Students From 1999 - 2008

\begin{tabular}{llll}
\hline & $\mathbf{1 9 9 9}$ & $\mathbf{2 0 0 8}$ & Growth \% \\
\hline Enrolled & 282,433 & 759,914 & 62.8 \\
New Entrants & 83,486 & 280,518 & 70.2 \\
Graduates & 38,067 & 111,955 & 66.0 \\
\hline
\end{tabular}

Source: Ministry of Higher Education, KSA

In the same context, the private sector has increased its contribution towards higher education. That led to an increase in the number of private universities to 8 and 19 private colleges, with a total of more the 26000 students. On the other hand, the Scholarship Program of King Abdullah bin Abdul Aziz also contributes in supporting disciplines where there is a shortage, such as medicine and medical science, engineering and technology. Male and female students are sent to attend advanced international universities, in more than 23 countries, including the United States, Canada, Australia, New Zealand, France, Japan, and Malaysia (SAMOEP, 2010).

Developing an innovative system focusing on research and development: In the era of knowledge and technology, R\&D has become an essential factor for the competiveness and prosperity of the economy. Many of the developed and developing countries are realizing its direct correlation with the national economy. The government of Saudi Arabia is trying to cooperate with the global transformation of research and development as well. That is noticeable from the substantial increase on its spending on R\&D where it has grown from $0.25 \%$ of GDP in 2000 to 1\% between 2010 and 2015 (AL-Sultan and Alzaharnah, 2012). The Eighth Developmental Plan focused on the development of the science and technology system, encouragement of scientific research and movement towards a knowledge based economy in order to achieve economic growth and competitiveness. In 2008, the Kingdom had 72 research centers at universities that conducted more than 1700 research and scientific publications. There were more than 3600 research studies and scientific papers authored or co-authored by faculty members that were published in scientific journals (SAMOEP, 2010). During the Ninth Developmental Plan (2010-2014), the government plans to invest 240 million dollars per year for strategic research centers and the establishment of 15 King Abdullah Cities for Science and Technology (KACST), which will be affiliated to the national technological innovation centers in universities. Moreover, it plans to establish 10 distinguished research centers. The forecast expenditure for the Human Resources development sector is around $\$ 195.1$ billion with an increase of $52.4 \%$ in addition to the amount allocated during the Eighth Developmental Plan (Table 6).

Table (6): The Financial Requirements for the HRD Sector, During the Eighth and Ninth Development Plans Million \$

\begin{tabular}{llll}
\hline Development Sectors & $\begin{array}{l}\text { Eighth Plan } \\
\text { Financial Allocation }\end{array}$ & $\begin{array}{l}\text { Ninth Plan } \\
\text { Financial Requirements }\end{array}$ & $\begin{array}{l}\text { Growth } \\
\text { (\%) }\end{array}$ \\
\hline General Education & $94,490.6$ & $132,905.9$ & 40.7 \\
Higher Education & $27,859.2$ & $53,380.5$ & 91.6 \\
Technical and Vocational Training & $4,358.5$ & $6,170.1$ & 41.6 \\
Science, Technology and Innovation & 927.5 & $1,739.9$ & 87.6 \\
Institute of Public Administration & 358.5 & 862.0 & 150.5 \\
Total & $127,994.2$ & $195,058.5$ & 52.4 \\
\hline
\end{tabular}

Source: Ministry of Economy and Planning, KSA, 2010

One of the main functions of higher education in general and post graduation in particular is research and development activities. It contributes largely in the socioeconomic development. In 2006, Dhahran TechnoValley (DTV) was launched at the King Fahd University of Petroleum and Minerals (KFUPM). It focuses on the technological aspects of petroleum processes. DTV holds R\&D centers of large multinational and local industries. In another example, Dow Chemical Company is intending to cooperate with King Abdullah Cities for Science and Technology in a multimillion-dollar joint research framework venture to be more innovative 
in the chemical sector. Likewise, PetroRabigh is a joint venture plastic development park that has been set up by Sumitomo and Saudi ARAMCO at King Abdullah Economic City to develop chemical crackers (AL-Sultan and Alzaharnah, 2012). In 2008, The National Science and Technology Plan (NTSP) planned to invest $\$ 2.1$ billion to implement programs and projects that would result in knowledge production. One of those programs aimed at establishing a chain of cooperative Technology Innovative Centers (TICs) between leading universities in the Kingdom and the private industrial sector; by 2011, three of the major universities in the kingdom have established TICs (AL-Sultan and Alzaharnah, 2012). The added value of this initiative is that the carried out researches are on industrial related problems to make sure that it adds to the industry.

Building Information and Communication Technology (ICT): ICT has transformed the world in the modern era. That is by enabling innovation, increasing productivity and connecting people around the globe. Therefore, it has become one of the key factors for the development and prosperity of a competing economy. The government of Saudi Arabia has realized that fact and one of its main initiatives was the National Communication and Information Technology Plan (NCITP), which was approved in 2007. The government's vision of that plan is:

"The transformation into an information society and digital economy so as to increase productivity and provide Communications and IT services for all sectors of the society in all parts of the country and build a solid information industry that becomes a major source of income." (Ministry of Communications and Information Technology, 2005). The Eighth Developmental Plan has paid a lot of attention towards developing the science and technology systems and moving towards a knowledge-based economy. The ICT sector has witnessed a significant progress during this period; where the market of mobile-phone services was opened for competition and the fixed line telephone services was de regulated. By the end of 2008, more than 300 licenses were issued. Out of which 3 were for mobile phone providers, 4 for fixed line providers and 43 for internet providers. The increase in internet services will help in increasing the dissemination of various eservices. The total number of mobile subscriptions rose to around 53.7 million in 2011 from 9.2 million in 2004. Similarly, the estimated number of Internet users in the Kingdom is 13.6 million by the end of 2011 compared to 2.4 million in 2004 (Table 5).

Table (5): The ICT Sector in the Kingdom of Saudi Arabia Subscriptions in Million

\begin{tabular}{lllll}
\hline & $\mathbf{2 0 0 1}$ & $\mathbf{2 0 0 4}$ & $\mathbf{2 0 0 9}$ & $\mathbf{2 0 1 1}$ \\
\hline Mobile & 2.5 & 9.2 & 44.8 & 53.7 \\
Subscription & 1.0 & 2.4 & 10.3 & 13.6 \\
Internet &
\end{tabular}

Source: Communications and Information Technology Commission, KSA, 2012

The government of Saudi Arabia has also launched a National e-Government Program called YESSER to improve the services provided by the public sector and build the foundation for a knowledge-based economy (Dutta and Mia, 2011). It has also adopted many policies like tariff regulations, anti-spam guidelines, and an awareness campaign to foster the correct use of ICT products and services to enhance the competitiveness and the supportiveness of the ICT. The initial goals of the program were to ensure the secure flow of government information, delivery of secure online services and provide organizational infrastructure to help government agencies successfully develop and implement their e- Government Transformation Plans. In the second phase, the government is focusing on creating a skilled workforce. As the country is moving towards a technology enabled government and knowledge society, the development of Saudi human capital is its main focus.

\section{Analysis of the Initiatives taken by the Saudi Arabian government for promoting a Knowledge- Based Economy}

The following section is an analysis of the initiative taken by the government of Saudi Arabia focusing on the four pillars of a knowledge-based economy, government development plans, education, research and development and information and communication technology. 
Government Development Plans: The Kingdom of Saudi Arabia has achieved an immense growth during the last four decades in many aspects like economy, education and standards of living. This can be witnessed through the increase in the GDP from SR 20.18 billion in 1970 to SR 855.765 billion in 2009. The university enrolment rate has risen from 5,352 students in 1969 to 759,914 students in 2008 and the per capita GDP has jumped from SR 3,185 to SR 46,200 in the period from 1970 to 2009. Unfortunately, there is no triumph without struggle. The government of Saudi Arabia faces a number of challenges that might cripple its progress in achieving the desired result of its development plans unless they are resolved. Such challenges are the dramatic increase in the population of the youth, women participation in the labor market and the implementation of those plans. The real challenge facing the government of Saudi Arabia is the increasing number of youth as the percentage of population under 15 years old which represents $37 \%$ of the total population whilst the age group 15-24 represents $21 \%$ of the total population in 2009 (UNDP, 2009). Therefore, the way the government would tackle the education, employment and health needs of this large young population will define the future of Saudi Arabia. Increased unemployment of educated youth is another major challenge especially among females. Women participation in the labor market remains low representing $14 \%$ of the labor force in 2009 . Out of which $85.8 \%$ of female labor is in the education sector, $6.1 \%$ in the health and social services and $4.4 \%$ in the public administration. The total unemployment stands at $21.7 \%$ for females and $7.6 \%$ for males (UNDP, 2009). One cannot deny the immense efforts the government of Saudi Arabia has paid in its projection of the five years developmental plan. However, its implementation is of utmost importance, For example, $85 \%$ of government projects in the Ministry of Municipal and Rural Affairs failed to meet their deadlines (Osaimi, 2012). Unfortunately, such delays could cripple the development of the country without doubt. Therefore, the government needs to pay as much attention to the implementation phase as it does for the planning phase in order for the country to develop and prosper.

Education: Building a knowledge-based economy to support sustainability of economic growth and development is a key challenge to the efforts aimed at diversifying the economic base and enhancing the competitiveness of the national economy and its export potential. To meet this challenge, the government included numerous policies and programs in the Eighth and Ninth Developmental Plans. They involve building national workforce and technological infrastructure; development of science, technology and innovation. Despite the dramatic expansion in institutions, programs, and students enrolment, higher education continues to fall short of the needs of employers. In 2010, the number of Saudi workers in the private sector was 0.7 million while the non-Saudi work force was 6.3 million (SAMA, 2011). One reason could be the gap between the educations that young Saudis receive and the skills demanded by the labour market. For example, during the education period much emphasis has been given on theories and memorizing rather than application and practicing that which is demanded by the labour market (Kirchberger, 2001).

Another reason could be that large numbers of students are pursuing degrees that are not required by the market. For example according to UNESCO, the single-largest majors chosen by Saudi students are humanities and arts representing 41\% of total university graduates in 2009 (Banque Saudi Fransi, 2011). Likewise, gender, the illiteracy rate for women (28.9\%) is almost triples the rate for men $(11.1 \%)$. As for secondary education, $61 \%$ of females enroll in social studies while $65 \%$ of males enroll in scientific and applied disciplines. That could be one of the reasons behind the high unemployment rate for females than it is for males whereby their subjects are not related to the labor market of the Saudi economy. Therefore, the Ministry of Education and the Ministry of Higher Education should initiate awareness programs that shed light on the economic directions of the country and the different specializations needed for that, targeting students in their early stages of education. Such initiatives would widen their horizons and lessen the gap between education outputs and labor market needs and will not only help in employing Saudi youth but will help in reducing the high number of expatriate workers in the country also.

Research and Development: There is no doubt that the government of Saudi Arabia realizes the essence of innovation and R\&D in developing a knowledge-based economy. The increased number of Research Chairs from 50 in 2007 to 221 by the end of 2011 is evident enough (Al Hamazani, 2012). The main objective of those chairs is to reduce the huge gap between academic researches and the private sectors needs. With all the efforts the government of Saudi Arabia is doing, still there is a shortfall between Research Chairs subjects and the private sectors needs. For example, one third of those chairs are for humanities and social science 
studies though these subjects are not of a pressing need for the national economy compared with engineering and medicine (Al Hamazani, 2012). Also, the Global Competitiveness Report 2012-2013 that covers 144 countries around the world, by looking at the innovation pillar, reveals that Saudi Arabia excel in "Government procurement of advanced technology products" by being ranked $5^{\text {th }}$ globally. On the contrary, it lacks in parameters like "Quality of scientific research institutions" ranking 37th, "University-industry collaboration in R\&D" ranking $31^{\text {st }}$ and number of patents where it ranked 49 $9^{\text {th }}$ (Schwab, 2012). As production of knowledge is carried out through R\&D and innovation activities, R\&D expenditure in Saudi Arabia is very low as a proportion of its GDP. There may be benefits from encouraging either domestically owned firms to engage in more R\&D, or encouraging foreign firms to locate more R\&D activities in Saudi Arabia. For these reasons, research centers might try to achieve the goal of the private sector from research. The private sector aims out of R\&D would be for one of three possibilities either for reducing the inputs, increasing the outputs or community services. By keeping this in minds, universities and research centers could attract the private sectors to finance their project, which benefits all.

Information and Communication Technology: Saudi Arabia is developing remarkably in the ICT sector in recent years. According to the Technological Readiness Pillar in the Global Competitiveness Index report (2012), Saudi Arabia has jumped from $40^{\text {th }}$ position in 2009 to $8^{\text {th }}$ position in 2012 in the parameter "FDI and technology transfer". Such improvements show the amount of importance the government of Saudi Arabia is giving towards developing the ICT sector to facilitate the transition of the economy to a knowledge-based one. On the other hand, the sector still needs further improvement. That can be realized from the fact that only $38.3 \%$ of the populations of Saudi Arabia were internet users in 2009. This percentage is relatively small when compared with developed countries such as UK where the number of internet users were $83.56 \%$ of its population in the same year (Saudi Arabian Ministry of Communications and Technology, 2010). The government of Saudi Arabia has initiated the E-government program (YESSER), the lack of technical awareness and knowledge of the employees in the public sector could cripple its efforts. Another issue is that most of the Saudi agencies have their own websites but they only provide basic and general information about the organization. Moreover, they lack recent statistics and most of the times the information posted on the websites are outdated. A key role for the government in terms of enhancing ICT will be through enabling investment in infrastructure, especially for broadband. In addition, encouraging Internet use among nonusers could be accomplished by increasing the availability of online Arabic content; also through promoting a culture of productive technology use from early stages of education.

\section{Conclusion}

The government of Saudi Arabia has laid the foundation for transforming its economy to a knowledge-based one during the period of the Eighth Developmental Plan by adopting the national ICT plan and establishing knowledge economic cities across the Kingdom among other initiatives. It continues its efforts in the Ninth Developmental Plan through adopting the drive towards a knowledge-based economy by focusing on human resources development to enhance its competitiveness and production. About the four pillars that have been analyzed in the previous sections, one can sum up that the Kingdom of Saudi Arabia is rapidly progressing. However, more is required especially in the field of human resource development and innovation to expedite the easiness of the process of transferring the economy into a knowledge-based one.

\section{References}

Al Hamazani, M. (2012). Chamber of Riyadh: it is time to benefit from the 221 Research Chairs" Al - Riyadh Online. Available at http://www.alriyadh.com/2012/07/23/article753962.html (Accessed on 29-112012)

AL-Sultan, K. S. \& Alzaharnah, I. T. (2012). Academia-Industry Innovation Linkages in the Case of Saudi Arabia: Developing a University-Industry Triple-Helix Framework to Promote Research and Development Collaboration. Chapter 3, the Global Innovation Index 2012. KFUPM, KSA: INSEAD. pp.91

Aubert, J. E. \& Reiffers, J. L. (2003). Knowledge economies in the Middle East and North Africa: Toward new development strategies, World Bank Publications. 
Banque Saudi Fransi. (2011). Saudi Arabia Economics. Available at http://www.google.co.in/url?sa=t\&rct=j\&q=\&esrc=s\&source=web\&cd=1\&cad=rja\&ved=0CCwQFjAA \&url=http\%3A\%2F\%2Fwww.alfransi.com.sa\%2Fen\%2Fgeneral\%2Fdownload\%2Ffile\%2F1045\&ei= I-CfUMLPE4zRrQeCu4CgCA\&usg=AFQjCNHQOsjSQg9Ihkbpfu0NJsn9T_umdA\&sig2=zuwifjBB6xYP57N-Jpi2w (Accessed on 8-11-2012)

Dutta, S. \& Mia, I. (2011). The global information technology report 2010-2011. World Economic Forum and INSEAD

Kirchberger, A. (2001). The knowledge economy and education reforms in MENA countries: Selected examples. Discussion Paper prepared for the World Bank.

Lawton, J. \& Clark, A. (1982). Foundation: The Introduction. Saudi Aramco World, 33(6), 4-5.

Mahdi, W. (2010). Analysts: population growth straining Saudi, Middle East Online (http://www.middle-eastonline.com/english/?id=38662) (Accessed on 10-11-2012)

Osaimi, N. (2012). 85\% of the government projects are crippled Al - Watan Online. Available at (http://www.alwatan.com.sa/local/News_Detail.aspx?ArticleID=122367\&CategoryID=5) (Accessed on 25-11-2012)

Saudi Arabian Ministry of Economy and Planning. (1975). Second Development Plan: Chapter2 Available at http://www.mep.gov.sa/themes/GoldenCarpet/index.jsp;jsessionid=B10E78F3953EA65A88C3A2F D0E9DFE8A.beta

Saudi Arabian Ministry of Economy and Planning. (1980). Third Development Plan: Chapter1 Available at http://www.mep.gov.sa/themes/GoldenCarpet/index.jsp;jsessionid=B10E78F3953EA65A88C3A2F D0E9DFE8A.beta

Saudi Arabian Ministry of Economy and Planning. (1985). Forth Development Plan: Chapter3 Available at http://www.mep.gov.sa/themes/GoldenCarpet/index.jsp;jsessionid=B10E78F3953EA65A88C3A2F D0E9DFE8A.beta

Saudi Arabian Ministry of Economy and Planning. (1990). Fifth Development Plan: Chapter3 Available at http://www.mep.gov.sa/themes/GoldenCarpet/index.jsp;jsessionid=B10E78F3953EA65A88C3A2F D0E9DFE8A.beta

Saudi Arabian Ministry of Economy and Planning. (1995). Sixth Development Plan: Chapter3 Available at http://www.mep.gov.sa/themes/GoldenCarpet/index.jsp;jsessionid=B10E78F3953EA65A88C3A2F D0E9DFE8A.beta

Saudi Arabian Ministry of Economy and Planning. (2000). Seventh Development Plan: Chapter3 Available at http://www.mep.gov.sa/themes/GoldenCarpet/index.jsp;jsessionid=B10E78F3953EA65A88C3A2F D0E9DFE8A.beta

Saudi Arabian Ministry of Economy and Planning. (2004). Eighth Development Plan: Chapter3 Available at http://www.mep.gov.sa/themes/GoldenCarpet/index.jsp;jsessionid=B10E78F3953EA65A88C3A2F D0E9DFE8A.beta

Saudi Arabian Ministry of Economy and Planning. (2010). Ninth Development Plan: Chapter9 Available at http://www.mep.gov.sa/themes/GoldenCarpet/index.jsp;jsessionid=3B197004BD51620746595C51 5631AC38.beta\#1352320870551

Saudi Arabian Ministry of Communications and Information Technology. (2005). The National Communications and Information Technology Plan: The vision towards the Information Society. Available at http://www.mcit.gov.sa/NR/rdonlyres/E8C255A7-E423-4F36-B9B3C5CAAB6AE87A/0/2NICTPEng.pdf?

Saudi Arabian Ministry of Communications and Technology. (2010). The Transformation into Information Society. Available at http://www.mcit.gov.sa/arabic/NICTP/Report/ (Accessed on 15-12-2012)

Saudi Arabian Monetary Agency (SAMA). (2011). Annual report Riyadh: Author

Schwab, K. (2012). The Global Competitiveness Report 2012-2013" World Economic Forum Available at http://www3.weforum.org/docs/WEF_GlobalCompetitivenessReport_2012-13.pdf (Accessed on 512-2012)

UNDP (2009), “UNDP Saudi Arabia Annual Report 2009” Available at (http://www.undp.org.sa/sa/documents/home/annual_report.pdf) (Accessed on 20-11-2012) 